\title{
A SIMPLE AND RAPID METHOD FOR THE SIMULTANEOUS DETERMINATION OF CALCIUM AND MAGNESIUM FROM THE SAME SAMPLE OF BLOOD SERUM
}

\author{
BY \\ G. S. KOVÁCS AND K. E. TÁRNOKY \\ From the Surgical Clinic, Medical University of Szeged, Szeged, Hungary
}

(RECEIVED FOR PUBLICATION FEBRUARY 10, 1959)

A simple and rapid procedure has been developed for the complexometric titration of serum calcium and magnesium using "plasmocorinth $\mathbf{B}$ " as indicator. Both determinations can be carried out from the same $0.5 \mathrm{ml}$. sample. The method is in good agreement with the established calcium and magnesium methods.

The generally used classic methods for the determination of serum calcium (Kramer and Tisdall, 1921) and magnesium (Denis, 1922) take time, and the results are obtained after a delay of one or two days, so hindering progress in the knowledge of the role played by these ions in physiology and pathology. Simpler methods were therefore sought for their determination. New methods were developed (Kingsley and Schaffert, 1953; Tsao, 1952; Natelson and Penniall, 1955; Greenberg and Mackey, 1932; Davis, 1955; Hirschfelder and Serles, 1934; Orange and Rhein, 1951; Vallee, 1954), but most of them were either cumbersome or inaccurate or required special equipment. Complexometric titration (Schwarzenbach, Biedermann, and Bangerter, 1946) with disodium ethylenediaminetetra-acetate (E.D.T.A.) seemed to be the most suitable among these procedures, although most of the indicators in use did not prove adequate, as the end-point of the titration was not sufficiently sharp and could not be established by simple visual observation. Recently new and suitable indicators have been reported for the simple determination of calcium (Diehl and Ellingboe, 1956 ; Patton and Reeder, 1956 ; Hildebrand and Reilley, 1957).

Yanagisawa (1955) and Kingsley and Robnett (1957) described a simple colorimetric procedure for the determination of serum calcium using the dye "plasmocorinth B" (Inabata Industry and Co. Ltd., Osaka, Japan). This dye is chemically very similar to the compounds recently recommended as indicators for the complexometric titration of calcium. The latter are derivatives of naphthylazo-naphthalene, whereas "plasmocorinth B" is a naphthyl-azo-benzene (disodium-1-hydroxy4-chloro-benzene-(2-azo-2)-1,8 dihydroxy-naphthalene-3,6-disulphonic acid).

In the course of preliminary experiments it was found that "plasmocorinth B"* may also be used as an indicator for the complexometric titration of calcium and magnesium. If E.D.T.A. is added in the presence of sodium hydroxide to a solution containing calcium and magnesium ions the dye, after having bound equivalent amounts of calcium, forms a bluish-violet soluble complex with E.D.T.A.; magnesium does not interfere with this reaction. In the presence of ammonium hydroxide, on the other hand, E.D.T.A. reacts with " plasmocorinth B" only after having bound both calcium and magnesium (Kovács and Tárnoky, 1959a).

This paper deals with a method for the determination of serum calcium and magnesium based on this principle, and a simple titrimetric determination for urinary calcium and magnesium developed from this method will be reported later.

\section{Reagents}

\section{Materials and Methods}

$0.001 M$ E.D.T.A. Solution.-Dissolve 0.3722 g. E.D.T.A. in $1,000 \mathrm{ml}$. distilled water. Standardize against $\mathrm{MgSO}_{4} .7 \mathrm{H}_{2} \mathrm{O}$.

$0.5 \mathrm{~N} \mathrm{NaOH}$.-Turbid solutions containing carbonate should not be used.

\footnotetext{
*Suppiied by the courtesy of Inabata Industry and Co. Ltd.
} 
Buffer Solution.--Dissolve $0.83 \mathrm{~g}$. $\mathrm{NH}_{4} \mathrm{Cl}$ in a small amount of water, add $12 \mathrm{ml}$. of concentrated $\mathrm{NH}_{4} \mathrm{OH}$, and fill to $100 \mathrm{ml}$. with distilled water.

\section{$0.5 \mathrm{~N} \mathrm{HCl}$.}

Indicator Solution.-Dissolve $10 \mathrm{mg}$. of " plasmocorinth B" in $100 \mathrm{ml}$. distilled water. Keep the solution in a dark bottle ; it can be used for at least six months.

The water used at the preparation of the solutions must be free of metal ions (twice-distilled water). The solutions should be preferably kept in polyethylene bottles. All glassware should be rinsed with twicedistilled water before use.

Procedure.-To $0.5 \mathrm{ml}$. of blood serum in a $50-\mathrm{ml}$. beaker add in succession $5 \mathrm{ml}$. distilled water, $1.5 \mathrm{ml}$. $0.5 \mathrm{~N} \mathrm{NaOH}$, and $1 \mathrm{ml}$. of the indicator solution. Titrate with 0.001 M E.D.T.A. from a 2 -ml. microburette to the first appearance of a bluish-violet colour. This end-colour develops sharply and does not change if more E.D.T.A. is added to the solution. Note the burette reading.

Add $1.2 \mathrm{ml} .0 .5 \mathrm{~N} \mathrm{HCl}$ to the same sample and mix thoroughly; the colour of the indicator will turn again to red. Pipette $1.5 \mathrm{ml}$. buffer solution to the sample and continue the titration to the first appearance of a light blue colour which also develops sharply and does not change on the addition of excess E.D.T.A.

Calcium is determined by the first titration and magnesium by the second. In the case of serial determinations care should be taken that not more than five to 10 minutes should elapse between the addition of $\mathrm{NaOH}$ and the beginning of the titration.

Calculation-One millilitre of 0.001 M E.D.T.A. solution is equivalent to $0.04008 \mathrm{mg} .=2 \mu \mathrm{Eq}$. calcium and $0.02432 \mathrm{mg} .=2 \mu \mathrm{Eq}$. magnesium respectively. Thus, the concentration of serum calcium and magnesium can be obtained according to the formula :

ml. (E.D.T.A. solution consumed for $\mathrm{Ca}) \times 8=\mathrm{Ca}$ (mg./ $100 \mathrm{ml}$.)

$\mathrm{ml}$. (consumed for $\mathrm{Mg}) \times 4.86=\mathrm{Mg}(\mathrm{mg} . / 100 \mathrm{ml}$.) or

ml. (consumed for $\mathrm{Ca}) \times 4=\mathrm{Ca}(\mathrm{mEq} . / 1$.)

$\mathrm{ml}$. (consumed for $\mathrm{Mg}) \times 4=\mathrm{Mg}(\mathrm{mEq} . / \mathrm{l}$.)

\section{Results}

The accuracy of the method was tested by comparing it with the oxalate method for calcium (Kramer and Tisdall, 1921) and the phosphate method for magnesium (Denis, 1922) determination (Table I).

With each method duplicate or triplicate determinations were made on every serum sample and the means of these values are given in Table I. (Many of the sera analysed were taken from uraemic patients, and some of them were haemolysed; presumably this may be the cause of

TABLE I

COMPARISON OF PROPOSED AND OXALATE (KRAMER AND TISDALL, 1921) AND PHOSPHATE METHODS (DENIS, 1922)

\begin{tabular}{|c|c|c|c|c|c|c|}
\hline \multirow{2}{*}{$\begin{array}{r}\text { Serum } \\
\text { Sample }\end{array}$} & \multicolumn{2}{|c|}{$\mathrm{Ca}(\mathrm{mg} . / 100 \mathrm{ml})}$. & \multirow{2}{*}{$\begin{array}{c}\text { Differ- } \\
\text { ence }\end{array}$} & \multicolumn{2}{|c|}{$\mathrm{Mg}$ (mg./100 ml.) } & \multirow[b]{2}{*}{ Difference } \\
\hline & $\begin{array}{c}\text { Oxal- } \\
\text { ate } \\
\text { Method }\end{array}$ & $\begin{array}{c}\text { Pro- } \\
\text { posed } \\
\text { Method }\end{array}$ & & $\begin{array}{l}\text { Phos- } \\
\text { phate } \\
\text { Method }\end{array}$ & $\begin{array}{c}\text { Pro- } \\
\text { posed } \\
\text { Method }\end{array}$ & \\
\hline \multirow{3}{*}{$\begin{array}{r}1 \\
2 \\
3 \\
4 \\
5 \\
6 \\
7 \\
8 \\
9 \\
10 \\
11 \\
12 \\
13 \\
14 \\
15 \\
16 \\
17 \\
18 \\
19 \\
20 \\
21 \\
22 \\
23 \\
24 \\
25 \\
26 \\
27 \\
28\end{array}$} & $\begin{array}{r}10.4 \\
10.9 \\
10.3 \\
10.3 \\
9.3 \\
9.0 \\
9.9 \\
10.1 \\
9.9 \\
10.0 \\
10.5 \\
9.7 \\
11.4 \\
9.4 \\
8.8 \\
9.1 \\
9.8\end{array}$ & $\begin{array}{r}10.4 \\
10.9 \\
10.3 \\
10.2 \\
9.4 \\
9 \cdot 1 \\
9.7 \\
9.8 \\
9.7 \\
9.7 \\
10.4 \\
9.5 \\
11.0 \\
9.3 \\
8.6 \\
8.8 \\
9.6\end{array}$ & $\begin{array}{r}0.0 \\
0.0 \\
0.0 \\
-0.1 \\
+0.1 \\
+0.1 \\
-0.2 \\
-0.3 \\
-0.2 \\
-0.3 \\
-0.1 \\
-0.2 \\
-0.4 \\
-0.1 \\
-0.2 \\
-0.3 \\
-0.2\end{array}$ & $\begin{array}{l}3 \cdot 60 \\
2 \cdot 76 \\
3 \cdot 82 \\
4 \cdot 00 \\
2 \cdot 52 \\
2.90 \\
3 \cdot 32 \\
3 \cdot 02 \\
3 \cdot 10\end{array}$ & $\begin{array}{l}3 \cdot 78 \\
3 \cdot 00 \\
4 \cdot 00 \\
4 \cdot 20 \\
2 \cdot 75 \\
2 \cdot 75 \\
3 \cdot 30 \\
2 \cdot 98 \\
2 \cdot 92\end{array}$ & $\begin{array}{r}+0.18 \\
+0.24 \\
+0.18 \\
+0.20 \\
+0.23 \\
-0.15 \\
-0.02 \\
-0.04 \\
-0.18\end{array}$ \\
\hline & $\begin{array}{r}9 \cdot 9 \\
9 \cdot 8 \\
10 \cdot 7 \\
8 \cdot 4 \\
9 \cdot 3 \\
9 \cdot 6 \\
9 \cdot 5 \\
8 \cdot 4 \\
10 \cdot 1 \\
10 \cdot 1 \\
9 \cdot 3\end{array}$ & $\begin{array}{r}9 \cdot 9 \\
9 \cdot 9 \\
10 \cdot 8 \\
8 \cdot 3 \\
9 \cdot 2 \\
9 \cdot 4 \\
9 \cdot 5 \\
8 \cdot 2 \\
10 \cdot 0 \\
9 \cdot 9 \\
9 \cdot 4\end{array}$ & $\begin{array}{r}+0.2 \\
+0.1 \\
-0.1 \\
-0.1 \\
-0.2 \\
0.0 \\
-0.2 \\
-0.1 \\
-0.2 \\
+0.1\end{array}$ & $\begin{array}{l}3.20 \\
2.62 \\
2.54 \\
2.46 \\
2.60 \\
1.95 \\
2.45 \\
1.95 \\
2.80\end{array}$ & $\begin{array}{l}3.02 \\
3.00 \\
2 \cdot 70 \\
2 \cdot 50 \\
2.55 \\
2 \cdot 15 \\
2.60 \\
2 \cdot 30 \\
2 \cdot 78\end{array}$ & $\begin{array}{r}-0.18 \\
+0.38 \\
+0.16 \\
+0.04 \\
-0.05 \\
+0.20 \\
+0.15 \\
+0.35 \\
-0.02\end{array}$ \\
\hline & \multicolumn{2}{|c|}{$\begin{array}{l}\text { Average of the } \\
\text { difference.. }\end{array}$} & $-0 \cdot 1$ & \multicolumn{2}{|c|}{$\begin{array}{l}\text { Average of the } \\
\text { difference.. }\end{array}$} & +0.09 \\
\hline
\end{tabular}

TABLE II

RECOVERY OF ADDED CALCIUM AND MAGNESIUM FROM POOLED SERUM

\begin{tabular}{|c|c|c|c|c|c|c|c|c|c|}
\hline Sample No. & 1 & 2 & 3 & 4 & 5 & 6 & 7 & 8 & 9 \\
\hline $\begin{array}{l}\text { Ca in sample }(\mu \mathrm{gg}) \\
\text { Ca added }(\mu \mathrm{g} .) \\
\text { Ca found }(\mu \mathrm{g} .) \\
\text { Ca calculated }(\mu \mathrm{g} .)\end{array}$ & $\begin{array}{r}52 \cdot 4 \\
0.0 \\
52 \cdot 4 \\
52 \cdot 4\end{array}$ & $\begin{array}{r}52 \cdot 4 \\
52 \cdot 9 \\
103 \cdot 0 \\
105 \cdot 3\end{array}$ & $\begin{array}{r}52.4 \\
0.0 \\
53.4 \\
52.4\end{array}$ & $\begin{array}{r}52 \cdot 4 \\
52 \cdot 9 \\
106 \cdot 1 \\
105 \cdot 3\end{array}$ & $\begin{array}{r}52.4 \\
102.5 \\
155.0 \\
154.9\end{array}$ & $\begin{array}{r}52.4 \\
0.0 \\
54.6 \\
52.4\end{array}$ & $\begin{array}{r}52.4 \\
102.5 \\
155 \cdot 3 \\
154.9\end{array}$ & $\begin{array}{r}52.4 \\
102.5 \\
155.1 \\
154.9\end{array}$ & $\begin{array}{r}52 \cdot 4 \\
52 \cdot 9 \\
105 \cdot 9 \\
105 \cdot 3\end{array}$ \\
\hline$\frac{\text { Ca found }}{\text { Ca calculated }}(\%)$ & $100 \cdot 0$ & 97.5 & 102.0 & 100.6 & $100 \cdot 1$ & $104 \cdot 2$ & $100 \cdot 4$ & $100 \cdot 1$ & $100 \cdot 4$ \\
\hline $\begin{array}{l}\text { Mg in sample }(\mu \mathrm{g} .) \\
\text { Mg added }(\mu \mathrm{g} .) \\
\text { Mg found }(\mu \mathrm{g} .) \\
\text { Mg calculated }(\mu \mathrm{g} .)\end{array}$ & $\begin{array}{r}14 \cdot 5 \\
0.0 \\
14.5 \\
14.5\end{array}$ & $\begin{array}{r}14 \cdot 5 \\
0 \cdot 0 \\
15 \cdot 1 \\
14 \cdot 5\end{array}$ & $\begin{array}{l}14 \cdot 5 \\
17 \cdot 4 \\
30 \cdot 7 \\
31 \cdot 9\end{array}$ & $\begin{array}{l}14.5 \\
17.4 \\
31.8 \\
31.9\end{array}$ & $\begin{array}{r}14.5 \\
0.0 \\
14.9 \\
14.5\end{array}$ & $\begin{array}{l}14 \cdot 5 \\
33 \cdot 5 \\
48 \cdot 9 \\
48 \cdot 0\end{array}$ & $\begin{array}{l}14 \cdot 5 \\
33 \cdot 5 \\
49 \cdot 2 \\
48 \cdot 0\end{array}$ & $\begin{array}{l}14 \cdot 5 \\
17 \cdot 4 \\
32 \cdot 5 \\
31 \cdot 9\end{array}$ & $\begin{array}{l}14 \cdot 5 \\
33 \cdot 5 \\
48 \cdot 1 \\
48 \cdot 0\end{array}$ \\
\hline$\frac{\mathrm{Mg} \text { found }}{\text { Mg calculated }}(\%)$ & $100 \cdot 0$ & $104 \cdot 2$ & $96 \cdot 3$ & $99 \cdot 7$ & 102.9 & $102 \cdot 0$ & $102 \cdot 8$ & $102 \cdot 0$ & $100 \cdot 2$ \\
\hline
\end{tabular}


the high magnesium concentration found in some of the samples.) Good agreement was obtained with the different methods.

Varying amounts of calcium and magnesium were added to $0.5 \mathrm{ml}$. samples of pooled serum and the specimens were titrated as described above. The recovery of the added calcium ranged from 97.5 to $104.2 \%$, with an average of $100.4 \%$, and for magnesium the recoveries ranged from 96.3 to $104.2 \%$, with an average of $101.3 \%$ (Table II).

The precision of the method was determined by calculating the standard deviations (Copeland, 1957) of 25 duplicate determinations. Thus, values for calcium determination, S.D. $= \pm 0.23$ $\mathrm{mg} . / 100 \mathrm{ml}$., and for magnesium, S.D. $= \pm 0.20$ $\mathrm{mg}$. $/ 100 \mathrm{ml}$., were obtained.

\section{Addendum}

Since the completion of this work a complexometric method for serum calcium has been published using " eriochromblue SE" (Geigy AG., Basel, Switzerland) as indicator (Flaschka, Abd
El Raheem, and Sadek, 1958). According to our 을 information this substance is chemically identical $\overrightarrow{\vec{D}}$ with " plasmocorinth B." Several determinations have proved that "eriochromblue SE"* is just as suitable as "plasmocorinth $\mathrm{B}$ " in the above procedure.

\section{REFERENCES}

Copeland, B. E. (1957). Amer. J. clin. Path., $27,551$.

Davis, S. (1955). J. biol. Chem., 216, 643.

Denis, W. (1922). Ibid., 52,411.

Diehl, H., and Ellingboe, J. L. (1956). Analyt. Chem., 28, 882.

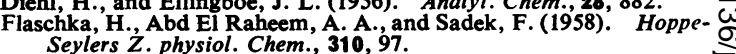

Greenberg, D. M., and Mackey, M. A.(1932). J.biol. Chem.,96, 419. Hildebrand, G. P., and Reilley, C. N. (1957). Analyt. Chem., 29, 258.

Hirschfelder, A. D., and Serles, E. R.(1934). J.biol.Chem.,104,635. $\rightarrow$ Kingsley, G.R., and Robnett, O.(1957) Amer.J.clin. Path.,27, 223. $\omega$ 1 and Schaffert, R. R. (1953). Analyt. Chem., 25, 1738. Kovács, G. S., and Tárnoky, K. E. (1959a). Anal. chim. Acta, 21, 297. :(1959b). Zschr. inn. Med., 14,887.

Kramer, B., and Tisdall, F. F. (1921). J.biol. Chem., 48, 223.

Natelson, S., and Penniall, R. (1955). Analyt. Chem., 27, 434.

Orange, M., and Rhein, H. C. (1951). J. biol Chem., 189, 379.

Patton, J., and Reeder, W. (1956). Analyt. Chem., 28, 1026.

Schwarzenbach, G., Biedermann, W., and Bangerter, F. (1946). Helv. chim. Acta, 29, 811 .

Tsao, M. U. (1952). J. biol. Chem., 199, 251.

Vallee, B. L. (1954), Nature (Lond.), 174, 1050.

Yanagisawa, F. (1955). J. Biochem., 42, 3. * The authors express their appreciation to Geigy AG., Basel,
for the generous supply of "eriochromblue SE." 